\section{Extra-Long First-Strand cDNA Synthesis}

\section{BioTechniques 32:984-985 (May 2002)}

To prepare representative full-length cDNA libraries $(1,2,4-6,8,9)$, we have been developing improved conditions for synthesizing long first-strand cDNA synthesis based on trehalosethermoactivated reverse transcriptase (3). Here we present improved protocols based on various osmolites (trehalose and sorbitol) and a commercially available buffer that allows the synthesis of cDNAs that exceed $23 \mathrm{~kb}$ in size. The protocols' volumes, which are designed to prepare cDNA on a large scale, can be scaled down for minor quantities of RNA.

Protocol 1. To prepare the firststrand cDNA, combine the following reagents in two different $0.5-\mathrm{mL}$ PCR tubes (A and B). In tube A, add 2.5-25 $\mu \mathrm{g}$ mRNA or $5-50 \mu \mathrm{g}$ total RNA, $14 \mu \mathrm{g}$ first-strand cDNA primer $(60 \mathrm{nM} / \mathrm{L})$ in the case of primer adaptors (4), and adjust the volume to $21.3 \mu \mathrm{L}$. The sample should not contain traces of ethanol from the previous precipitation steps because it will affect the reverse transcriptase. To melt the secondary structures of the mRNA, heat the mixture at $65^{\circ} \mathrm{C}$ for 10 min, during which the following mixture (tube B) should be prepared quickly. In a final volume of $76 \mu \mathrm{L}$, add 28.6 $\mu \mathrm{L}$ SUPERSCRIPT ${ }^{\mathrm{TM}}$ II $5 \times$ first-strand buffer (Invitrogen, Tokyo, Japan), $11 \mu \mathrm{L}$ $0.1 \mathrm{M}$ DTT, $9.3 \mu \mathrm{L}$ dNTP mixture, 10 $\mathrm{mM}$ each $(625 \mu \mathrm{M}$ dNTPs; in the case of hemimethylated cDNA, use 5methyl-dCTP instead of dCTP), $55.4 \mu \mathrm{L}$ 4.9 M sorbitol (1.90 M; Fluka, Tokyo, Japan), $23.2 \mu \mathrm{L}$ saturated trehalose (about $75 \% \mathrm{w} / \mathrm{v}$, final concentration, 356 $\mathrm{mM}$ ) (Fluka), and 15.0 $\mu \mathrm{L}$ RNase $\mathrm{H}$ SUPERSCRIPT II reverse transcriptase (200 U/ $\mu \mathrm{L}$ ) (Invitrogen). [ $\alpha-32 \mathrm{P}] \mathrm{dGTP}$ can be used as tracer in this study. The final volume is brought to $142.5 \mu \mathrm{L}$ with RNase-free double-distilled water. Additionally, $150 \mathrm{ng} / \mu \mathrm{L}$ of the reaction of the T4 gene 32 (Amersham Biosciences, Tokyo, Japan) were added where indicated in the Figure 1 legend.

After the denaturation of the RNA (tube A), mix with the enzyme mixture (tube B) on a thermal cycler after a brief preheating at $40^{\circ} \mathrm{C}$ (for a hot start), followed by 4 min incubation at $40^{\circ} \mathrm{C}, 2 \mathrm{~min}$ at $50^{\circ} \mathrm{C}$, and $60 \mathrm{~min}$ at $56^{\circ} \mathrm{C}$. The reaction can then be terminated by the addition of EDTA or further processed as desired. For a cold start reaction, the content of tubes $\mathrm{A}$ and $\mathrm{B}$ can be mixed on ice and subsequently transferred quickly to the thermal cycler, programmed as for the hot start. Although handling is simplified, internal priming is a major concern in cold start reactions.

Control of protocol 1. The control reactions were performed using the SUPERSCRIPT II reagents as indicated by the manufacturer, although we increased the volume of the reagent for an appropriate comparison. The same amount of enzyme was used.

Protocol 2. The RNA (tube A) is prepared as for Protocol 1. The reaction mixture (tube B) contains the following components: $75 \mu \mathrm{L} 2 \times$ GC-I buffer, originally designed for the LA-Taq DNA polymerase (Takara, Shiga, Japan); $4 \mu \mathrm{L} 10 \mathrm{mM}$ each dNTPs (312 $\mu \mathrm{M}) ; 766 \mathrm{mM}$ sorbitol; $10 \mu \mathrm{L}$ saturated trehalose (approximately 75\%; final concentration, $170 \mathrm{mM}) ; 15 \mu \mathrm{L}$ SUPERSCRIPT II reverse transcriptase (200 U/ $\mu \mathrm{L})$ (Invitrogen), and double-distilled water up to a final concentration of 128 $\mu \mathrm{L}$. As for Protocol $1,\left[\alpha_{-}{ }^{32} \mathrm{P}\right] \mathrm{dGTP}$ can be used as tracer; $150 \mathrm{ng} / \mu \mathrm{L}$ (final concentration) $\mathrm{T} 4$ gene 32 protein was added where indicated in Figure 1. The hot start is the preferred protocol, although tubes A and B could be mixed on ice (cold start) as for Protocol 1. For the hot start, briefly preheat tubes $\mathrm{A}$ and $\mathrm{B}$ for $1 \mathrm{~min}$ at $42^{\circ} \mathrm{C}$, quickly mix and incubate at $42^{\circ} \mathrm{C}$ for $30 \mathrm{~min}$, followed by $10 \mathrm{~min}$ at $50^{\circ} \mathrm{C}$ and $10 \mathrm{~min}$ at $55^{\circ} \mathrm{C}$. The reaction can then be terminated and the cDNA used for further manipulations.

Control of protocol 2. Control reactions were performed using the $2 \times \mathrm{GC}$ I buffer without the trehalose and sorbitol. The reaction volume and the amount of enzyme used were the same.

The final concentrations of the dNTPs and osmolytes, which differ between the two protocols, was determined experimentally by preparing first-strand cDNAs at various conditions that were replicated at least twice.

Figure 1 shows that reactions using a poly (A) ${ }^{+}$RNA molecular weight marker (Invitrogen) with Protocols 1 and 2 (the reactions in the presence of trehalose and sorbitol) always exceed the control condition, both with the original SUPERSCRIPT II buffer and the GC-I buffer. The efficiency of the protocol was primarily evaluated by the efficiency of the synthesis of the fulllength cDNA from the 9.49-kb RNA and then from the lower molecular weight RNAs. Reactions with the GC-I buffer are usually effective in synthesizing very long, full-length cDNA, although residual non-full-length cDNAs (caused by either internal priming or truncation during the elongation) are visible. The addition of the T4 gene 32, which was recently reported to improve RT-PCR (10), apparently does not affect the first-strand synthesis under our conditions; therefore, we can possibly exclude the effect of T4 gene 32 on reverse transcriptase activity.

Next, we tried to synthesize cDNA using the most efficient reaction (Protocol 2), with mRNA prepared from total (whole) or cytoplasmic RNA. The cytoplasmic RNA was prepared by pelleting nuclei before RNA extraction (7) to

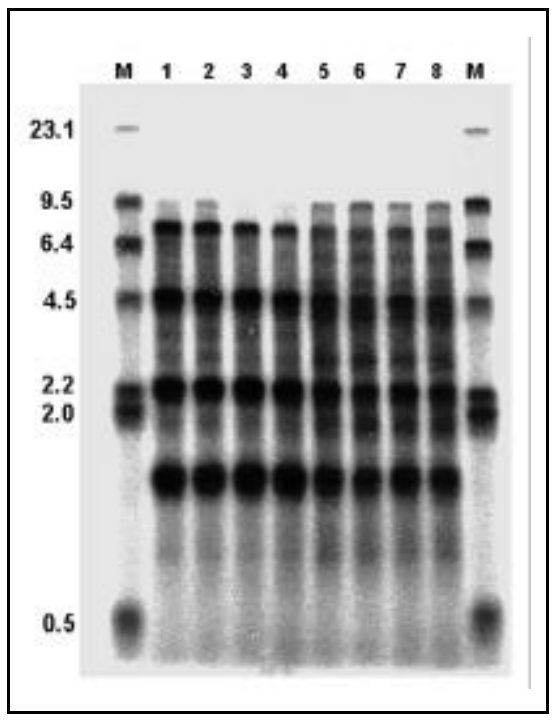

Figure 1. Efficiencies of the synthesis of fulllength cDNA with Protocols 1 and 2. M, molecular weight markers ( $\gamma$ HindIII). Lanes $1-4$, Protocol 1/control (SUPERSCRIPT II buffer), lanes 5-8, Protocol 2/controls (GC-I buffer). Trehalose and sorbitol were present in reactions $2,4,6$, and 8 ; T4 gene 32 was added to samples $3,4,7$, and 8 , according to the manufacturer's protocols. The sizes of the RNA ladder used in this experiment were $9.49,7.46,4.40,2.37$, and $1.35 \mathrm{~kb}$, respectively. 


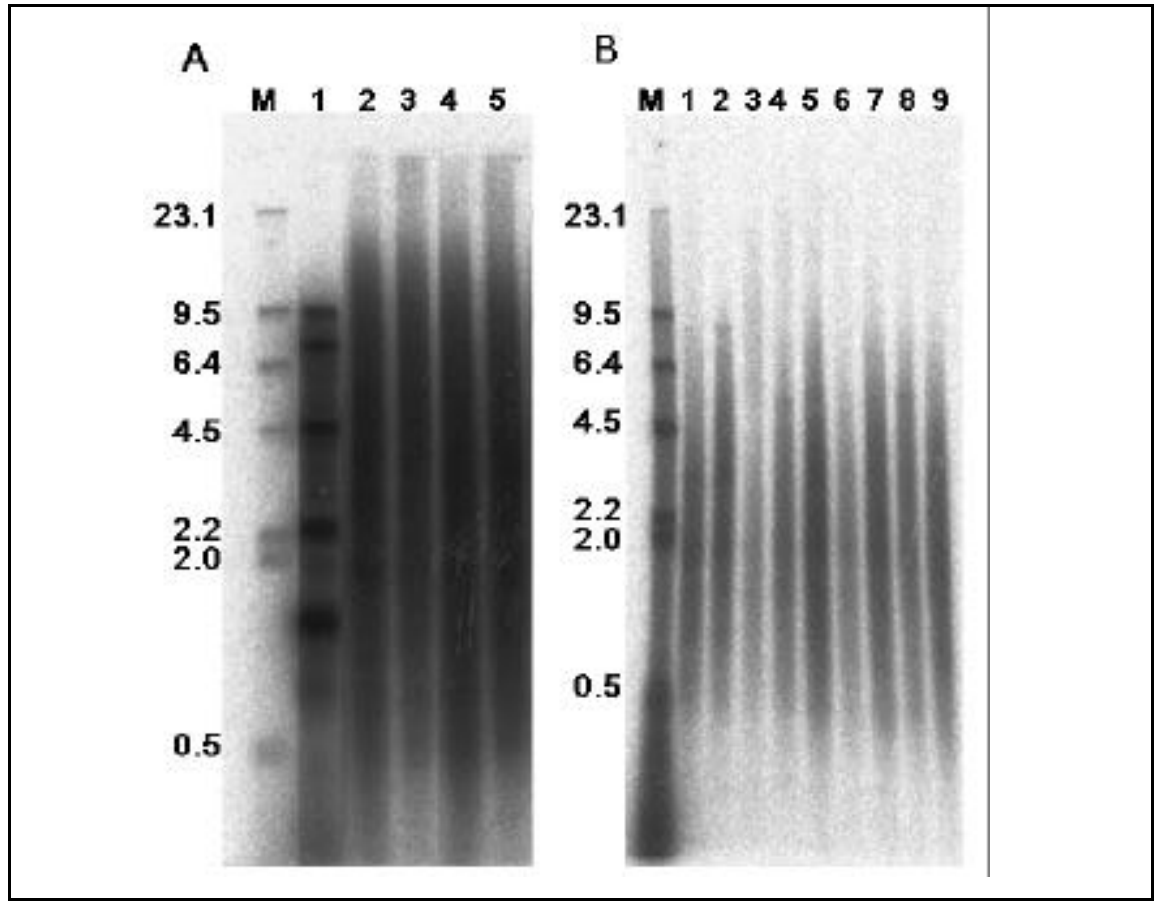

Figure 2. Best reactions with Protocol 2 using whole and cytoplasmic mRNA. (A) Reactions with mRNA from whole mouse RNA that contains residual, unspliced long RNAs. M, molecular weight marker. Lane 1, poly(A) RNA marker, hot start. Lanes 2 and 3, brain and lanes 4 and 5, thymus. Lanes 2 and 4, cold start and lanes 3 and 5, hot start. (B) Hot start reaction cDNA synthesis with mouse cell line cytoplasmic RNA. M, markers; lane 1, MBT-2 carcinoma; lane 2, Cle-H3; lane 3, K-1.F1 cell line; lane 4, WEH-1-3 myeloma; lane 5, B16 melanoma; lane 6, Meth-A sarcoma; lane 7, CRL 2070 nullipotent stem cell teratocarcinoma; lane 8, CRL2070 NE teratocarcinoma; and lane 9, CCL 142 RAG kidney cancer.

eliminate unspliced RNA. In Figure 2, we show that the cDNA can be longer than $23 \mathrm{~kb}$. To our knowledge, this is the best result published to date (3). Reactions with cytoplasmic RNA are usually shorter than reactions with total RNA because of the absence of residual introns and the general shorter nature of cytoplasmic RNA, although there are no convenient published protocols to reproducibly extract cytoplasmic RNA from whole tissues. The hot start reaction shows a reduction of cDNAs shorter than $0.5 \mathrm{~kb}$, suggesting that hot start is important to prevent both internal priming and premature reverse transcriptase termination.

These reaction conditions allow practically size-unlimited cDNA synthesis for full-length cDNA library construction, RT-PCR, and 5'-end rapid amplification of cDNA ends (RACE). The remaining factors necessary for effective cloning of cDNAs from very long mRNAs consist in the preparation of high-quality cytoplasmic RNA that is devoid of residual, unspliced introns from a wide variety of tissues (P. Carn- inci et al., submitted) and in the use of appropriate cloning vectors that can stabilize very long cDNAs encoding for proteins potentially toxic to bacterial hosts. Such methods will allow the isolation of full-length cDNAs for very long transcripts from human, mouse, and other model organisms, which is an essential step to identify genes and their corrected splicing isoforms and to express the encoded proteins.

\section{REFERENCES}

1.Carninci, P. and Y. Hayashizaki. 1999. High-efficiency full-length cDNA cloning. Methods Enzymol. 303:19-44.

2.Carninci, P., C. Kvam, A. Kitamura, T. Ohsumi, Y. Okazaki, M. Itoh, M.Kamiya, K. Shibata, et al. 1996. High efficiency fulllength cDNA cloning by biotinylated cap trapper. Genomics 37:327-336.

3.Carninci, P., Y. Nishiyama, A. Westover, M. Itoh, S. Nagaoka, N. Sasaki, Y. Okazaki, M. Muramatsu, et al. 1998. Thermostabilization and thermoactivation of thermolabile enzymes by trehalos. Proc. Natl. Acad. Sci. USA 95:520-524.

4.Carninci, P., Y. Shibata, N. Hayatsu, Y. Sugahara, K. Shibata, M. Itoh, H. Konno, Y.
Okazaki, et al. 2000. Normalization and subtraction of cap-trapper-selected cDNAs to prepare full-length cDNA libraries for rapid discovery of new genes. Genome Res. 10:1617-1630.

5.Carninci, P., A. Westover, Y. Nishiyama, T. Ohsumi, M. Itoh, S. Nagaoka, N. Sasaki, Y. Okazaki, et al. 1997. High efficiency selection of full-length cDNA by improved biotinylated cap trapper. DNA Research 4:61-66.

6.Kawai, J., A. Shinagawa, K. Shibata, M. Yoshino, M. Itoh, Y. Ishii, T. Arakawa, A. Hara, et al. 2001. Functional annotation of a full-length mouse cDNA collection. Nature 409:685-690.

7.Sambrook, J. and D.W. Rusell. 2001. Molecular Cloning: A Laboratory Manual. CSH Laboratory Press, Cold Spring Harbor, NY.

8.Shibata, Y., P. Carninci, A. Watahiki, T. Shiraki, H. Konno, M. Muramatsu, and Y. Hayashizaki. 2001. Cloning full-length, captrapper-selected cDNAs by using the singlestrand linker ligation method. BioTechniques 30:1250-1254.

9.Sugahara, Y., P. Carninci, M. Itoh, K. Shibata, H. Konno, T. Endo, M. Muramatsu, and Y. Hayashizaki. 2001. Comparative evaluation of 5'-end-sequence quality of clones in CAP trapper and other full-length-cDNA libraries. Gene 263:93-103.

10. Villalva, C., C. Touriol, P. Seurat, P. Trem pat, G. Delsol, and P. Brousset. 2001. Increased yield of PCR products by addition of T4 gene 32 protein to the SMART ${ }^{\mathrm{TM}} \mathrm{PCR}$ cDNA synthesis system. BioTechniques $31: 81-86$.

We thank N. Hayatsu, T. Hirozane, M. Nakamura, N. Sakazume, Y. Shibata, A. Watahiki, and K. Sato for their support and technical assistance. This study has been supported by a research grant for the RIKEN Genome Exploration Research Project and from the Human Genome Program from the Ministry of Education, Culture, Sports, Science, and Technology of the Japanese government. This work was also supported by a grant from the RIKEN Presidential Foundation for Innovative Tool Development to P.C. Address correspondence to Dr. Piero Carninci, Genome Science Laboratory, RIKEN, 21 Hirosawa, Saitama, 351-0198, Japan. email:rgscerg@gsc.riken.go.jp

Received 4 January 2002; accepted 14 February 2002.
P. Carninci'1, T. Shiraki1,2, Y. Mizuno' ${ }^{2}$ M. Muramatsu², and Y. Hayashizaki ${ }^{1,2}$
${ }^{1}$ RIKEN, Saitama
${ }^{2}$ RIKEN Genomic Sciences
Center
Yokohama, Kanagawa, Japan 